\title{
Pengaruh Blended Learing Berbasis Flipped Classroom pada Mata Pelajaran Prakarya Terhadap Hasil Belajar Siswa Kelas X SMK
}

\author{
Wiratama Darmawan, Dedi Kuswandi, Henry Praherdhiono \\ Magister Teknologi Pendidikan, Fakultas Ilmu Pendidikan, \\ Universitas Negeri Malang
}

\section{Edcomtech}

\author{
Jurnal Kajian \\ Teknologi Pendidikan \\ Volume 5, No 1, April 2020 \\ 170-179
}

Submitted 07-01-2020

Accepted 31-01-2020

Corresponding Author

Wiratama Darmawan

wiratama.darmawan@gmail.com

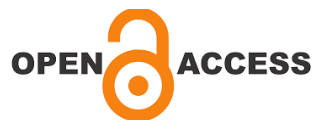

\begin{abstract}
Abstrak
Tujuan dari penelitian ini adalah untuk menguji pengaruh blended learning berbasis flipped classroom terhadap hasil belajar kelas X SMK Ma'arif Batu. Jenis penelitian yang digunakan adalah eksperimen semu/quasi eksperimen dengan pemilihan kelompok tidak acak (Pretest - Posttest Control Group Design) (Sugiyono, 2014). Teknik pengumpulan data yang digunakan adalah teknik tes. Pre-test dilakukan untuk mengambil data kemampuan awal siswa, sedangkan post-test dilakukan untuk menguji pengaruh perlakuan. Dalam penelitian ini akan dilakukan 3 uji statistik yaitu, (1) uji normalitas, (2) uji homogenitas, (3) uji hipotesis. Dengan demikian hipotesis yang telah dirumuskan dapat dibuktikan, yaitu $\mathrm{HO}$ ditolak dan $\mathrm{H} 1$ diterima karena nilai signifikansinya 0,000 <0,05 pada taraf signifikansi 5\% sehingga dapat disimpulkan bahwa ada pengaruh blended learning berbasis Flipped Classroom pada mata pelajaran Prakarya terhadap hasil belajar siswa kelas X SMK Ma'arif.
\end{abstract}

Kata Kunci: Model Blended Learning berbasis Flipped Classroom; Prakarya; Hasil Belajar

\begin{abstract}
The purpose of this study was to examine the effect of blended learning based flipped classroom on study prakarya to class X learning outcomes of Ma'arif Batu Vocational School. The type of research used is quasi-experimental with nonrandom group selection (Pre-test - Post-test Control Group Design) (Sugiyono, 2014). The data collection technique used is a test technique. The pre-test is done to retrieve a student's initial ability data, while the post-test is conducted to test the effect of treatment. In this study, three statistical tests will be carried out namely, (1) normality test, (2) homogeneity test, (3) hypothesis test. Thus the hypotheses that have been formulated can be proven, namely, $\mathrm{HO}$ is rejected and $\mathrm{H} 1$ is accepted because the significance value is $0,000<0.05$ at a significance level of $5 \%$ so that it can be concluded that There is an influence of blipped learning based on Flipped Classroom on the subjects of the Prakarya to learning outcomes of Grade X students of the Ma'arif Vocational School.
\end{abstract}

Keywords: Blended Learning Model based flipped Classroom; Prakarya; Learning Outcomes 


\section{PENDAHULUAN}

Pembelajaran merupakan sistem yang terintegrasi. Sebagaimana yang dinyatakan oleh Darwis Dasopang, pembelajaran adalah sistem dalam proses belajar, berisi tentang rangkaian peristiwa yang di rancang dan disusun sedemikian rupa untuk mendukung terjadinya proses belajar siswa yang bersifat internal. Pembelajaran sebagai sistem pasti tidak akan lepas dari komponen yang mendukung sistem itu sendiri. Ada lima komponen yang sangat penting dalam sistem pembelajaran yaitu tujuan (goal), materi (theory), metode (method), media (media), dan evaluasi pembelajaran (learning evaluation) (Pane \& Darwis Dasopang, 2017).

Pembelajaran juga erat kaitannya dengan penggunaan teknologi. Di era canggih ini kehadiran teknologi komputer dengan berbagai variasi aplikasi yang menyertainya menjadi peluang bagi guru untuk mengimplementasikan media pembelajaran. Media pembelajaran merupakan alat atau bahan yang berisi pesan sehingga dapat menunjang efisiensi dan efektivitas untuk mencapai tujuan pembelajaran (Panje et al., 2016)

Namun, masih banyak guru yang kurang terbiasa atau belum memanfaatkan media pembelajaran tersebut secara maksimal (Adhani, 2014; Baihaqi, 2017). Guru hanya menyiapkan materi pengajaran dan menyampaikannya secara lisan. Ada juga guru yang menyampaikan materi pembelajaran hanya dengan alat bantu seperti marker, dan papan tulis. Namun ada beberapa guru yang sudah terbiasa menggunakan teknologi komputer.

Identifkasi awal yang peneliti lakukan adalah observasi dan wawancara dengan guru mata pelajaran Prakarya di SMK Ma'arif, Kota Batu, Jawa Timur. Observasi dilaksanakan pada awal semester gasal dengan cara mengajukan beberapa wawancara tentang kesulitan guru dalam menyampaikan materi pembelajarannya. Contohnya ada pada bab simulasi rangkaian listrik seri atau paralel. Dari hasil wawancara, dapat disimpulkan bahwa siswa sering mengalami kesulitan dalam menerima materi praktikum dan menghafal komponen - komponen elektronika. Hal ini dapat disebabkan oleh kurangnya materi praktikum yang hanya dapat pelajari siswa saat didampingi oleh guru dan kurang menariknya strategi pembelajaran guru dalam menyampaikan materi yang bersifat menghafal. Menurut guru, ia sudah melakukan upaya untuk menggunakan media pembelajaran seperti PPT dan Video. Namun usaha itu dirasakan masih belum maksimal.

Berdasarkan keterangan siswa strategi pembelajaran yang digunakan guru untuk mengajar seperti belum bisa memenuhi kebutuhan belajar mereka. Siswa menginginkan suatu pembelajaran praktikum yang juga dapat dipelajari atau dipraktikkan manapun dan kapanpun serta memiliki kesan pelajaran yang menyenangkan terutama untuk mata pelajaran Prakarya. Menurut mereka mata pelajaran Prakarya adalah mata pelajaran yang mampu menumbuhkan kreativitas dan juga dapat menjadi modal mereka untuk berkarya untuk mendapat peluang kerja di masa depannya

Selain itu, jam pelajaran prakarya yang dirasa sangat singkat. Mata Pelajaran Prakarya hanya berlangsung selama 2 jam pelajaran atau 2x45 menit yang dirasa kurang apabila guru harus menerapkan 2 metode dalam 1 kali pembelajaran. Ketika hal ini terus terjadi maka akan ada kesenjangan antara tujuan pembelajaran dengan hasil belajar siswa. Maka dari itu guru perlu berinovasi untuk memberikan solusi yang berupa strategi pembelajaran baru dalam pembelajaran Prakarya di SMK Ma'arif.

Seiring dengan perkembangan teknologi dalam pembelajaran, banyak model dan metode pembelajaran yang telah dikembangkan (Abdul Hakim, Punadji Setyosari, I Nyoman Sudana Degeng, 2016; Dewi, 2018; Dwiyogo, 2014). Menurut peneliti dariberbagaipermasalahan diatas, maka harus ada model pembelajaran yang tepat sebagai strategi yang akurat dalam menyampaikan materi pembelajaran praktikum tersebut. Guru harus memberikan materi secara konvensional sebagai pengantar dan juga materi secara digital sebagai pengganti. Model pembelajaran yang ditawarkan yaitu blended learning berbasis flipped classroom dengan memanfaatkan berbagai macam 
platform pembelajaran secara virtual/online dengan didukung teknologi smartphone dan computer/laptop.

flipped classroom sering disebut kelas yang dibalik. Konsep dari Flipped Classrom itu sendiri yaitu yang pada umumya dilakukan dikelas kini juga dapat dipelajari di rumah dan apa yang dikerjakan di rumah dapat dilakukan dikelas (Bergmann \& Sams, 2014; Husamah, 2015; Kunti Farhatana TS1, Sunismi2, 2019; Mehring, 2017). Hal ini dapat melatih ketrampilan siswa secara mendalam karna dapat dilaksanakan siswa berkali-kali dirumah atau dimanapun dan kapanpun. Dengan didukung oleh platform online sehingga guru tetap bisa memantau siswa dalam forum pembelajaran yang telah disediakan oleh aplikasi/website pembantu yaitu Sipekad. Di dalam Sipekad itu sendiri telah didesain sedemikian rupa sehingga dapat membantu interaksi antara guru dan siswa seperti yang ada dalam Google Classrom yang sering kita kenal Learning Management System (LMS) (Mtebe, 2015; Praherdhiono et al., 2019).

Sedangkan pembelajaran berbasis Blended Learning yaitu kombinasi cara penyampaian materi pembelajaran melalui kegiatan tatap muka, bantuan komputer secara offline, dan online (Dwiyogo, 2018; Spanjers et al., 2015; Wentzel et al., 2016). Selain itu Blended Learning juga disebut pembelajaran tatap muka yang memanfaatkan media komputer (Ekayati, 2018). Blended learning merupakan metode baru yang mengombinasikan pembelajaran menggunakan media secara online berbantuan teknologi smartphone, komputer dan tablet dengan pembelajaran secara tradisional. Hal ini juga akan meningkatkan minat siswa pada mata pelajaran sehingga motivasi belajar siswa juga dapat meningkat. (Al Aslamiyah et al., 2019; Ridha et al., 2016). Siswa akan merasakan sensasi belajar yang bervariasi, tidak hanya belajar online saja atau bertatap muka saja (Abidin et al., 2019; Capone et al., 2017)

Dengan diterapkannya blended-learning dengan metode flipped classroom maka akan dapat memberikan pengalaman baru terhadap siswa dalam memahami materi pembelajaran. Siswa juga akan memahami materi secara mendalam, mudah dalam mencari materi suplement secara online dan mudah dalam mengerjakan praktikum dengan dibantu oleh beberapa video yang dapat diputar ulang dimanapun dan kapanpun(Hidayati et al., 2019; Ridha et al., 2016).

Hal ini juga pernah di teliti dilakukan penelitian yang serupa oleh (Ridha et al., 2016), melalui pengujian hipotesis kelompok eksperimen dengan hasil $(0.000<0.05)$ kemudian hasil dari kelompok kontrol yaitu $(0.003<0.05)$ ia menguji strategi pembelajaran dan menyatakan, bahwa "strategi flipped mastery classroom yang diterapkan pada kelompok eksperimen memberikan pengaruh yang berbeda dengan strategi tradisional yang diterapkan pada kelompok kontrol terhadap perolehan hasil belajar kognitif secara signifikan"(Ridha et al., 2016).

Selain itu dalam sebuah artikel jurnal yang ditulis Kunti dan Sunismi menyebutkan "terdapat perbedaan dalam kemampuan presentasi materi pelajaran matematika oleh siswa antara kelas eksperimen (melalui model blended learning dan metode flipped classroom) dan kelas kontrol (melalui model pembelajaran konvensional)" (Kunti Farhatana TS1, Sunismi2, 2019). Dengan hasil analisis data uji hipotesis sebesar $(0,000<0,05)$.

Banyak bahan ajar yang dapat mendukung berjalannya blended-learning dengan metode flipped classroom ini. Salah satunya adalah pemanfaatan Media Video ketika siswa mengejakan praktik di rumah, apa bila siswa belum paham/belum bisa mengikuti dalam 1 kali menonton video mereka dapat memutar ulang video tersebut hingga beberapa kali, mengingat setiap kemampuan memahami materi setiap siswa pun juga berbedabeda(Schwab-Cartas \& Mitchell, 2015). Selain itu guru juga dapat memberikan modul bergambar sehingga memberikan pemahaman yang mendalam hingga berkesan materi tersebut disampaikan dengan sedetail mungkin. Guru juga dapat memantau siswa dalam menerima materi dengan cara berinteraksi secara online melalui forum belajar online Google Classroom(Panje et al., 2016).

Google classroom adalah situs yang dirancang untuk membantu proses belajar(Maharani \& Kartini, 2019). Pada proses 
pembelajaran Google Classrom berkontribusi sebagai Website untuk mentransfer atau menyampaikan data pengguna melalui halaman Webyang didalamnya dapat diisi teks, gambar, video, file dan lain-lain(Praherdhiono et al., 2019). Dalam Google Classrom terdapat berbagai menu pilihan, diantaranya yaitu Google Classes untuk mendukung pembelajaran secara online(Wulandari et al., 2019). Dapat dikategorikan dalam e-learning maupun m-learning karena Google Classrom dapat diakses dalam beberbagai platform online seperti komputer, gadget smart-tv dan smartphone berbasis windows, mac ataupun android (Graham \& Borgen, 2018; Yuhefizar, 2016)

\section{METODE}

Dalam penelitian ini, desain penelitian yang dipakai oleh peneliti yaitu quasi experiment/ eksperimen semu yaitu rancangan pretest posttest dengan pemilihan kelompok tidak diacak/Untreatned Pretest-Posttest Control Group Design(Knapp, 2016). Desain penelitian menggunakan dua kelompok sampel yaitu kelompok eksperimen dan kelompok kontrol.
Desain penelitian yang digunakan adalah pada tabel di bawah ini:

Tabel 1. Rancangan Pretest-Posttest (Alatas et al., 2011)

\begin{tabular}{|l|l|l|l|}
\hline Pre-tes & Perlakuan & Post-test & Subjek \\
\hline Kel 1 & $><$ & Kel 1 & (Eksperimen) \\
\hline Kel 2 & & Kel 2 & (Kontrol) \\
\hline
\end{tabular}

Desain penelitian ini melibatkan satu kelompok eksperimen, dan satu kelompok kontrol, di mana kedua kelompok menerima perlakuan yang sama mengenai tujuan pembelajaran dan materi pelajaran yang diberikan, tetapi metode pembelajaran yang berbeda(Flammer \& Luo, 2017). Pada kelas eksperimen menggunakan Blended Learning berbasis flipped classroom sedangkan kelompok kontrol menggunakan metode Blended Learning menggunakan media pembelajaran. Kemampuan awal siswa diketahui dengan menggunakan nilai pretest. Dibawah ini merupakan gambar hubungan konseptual penelitian ini:

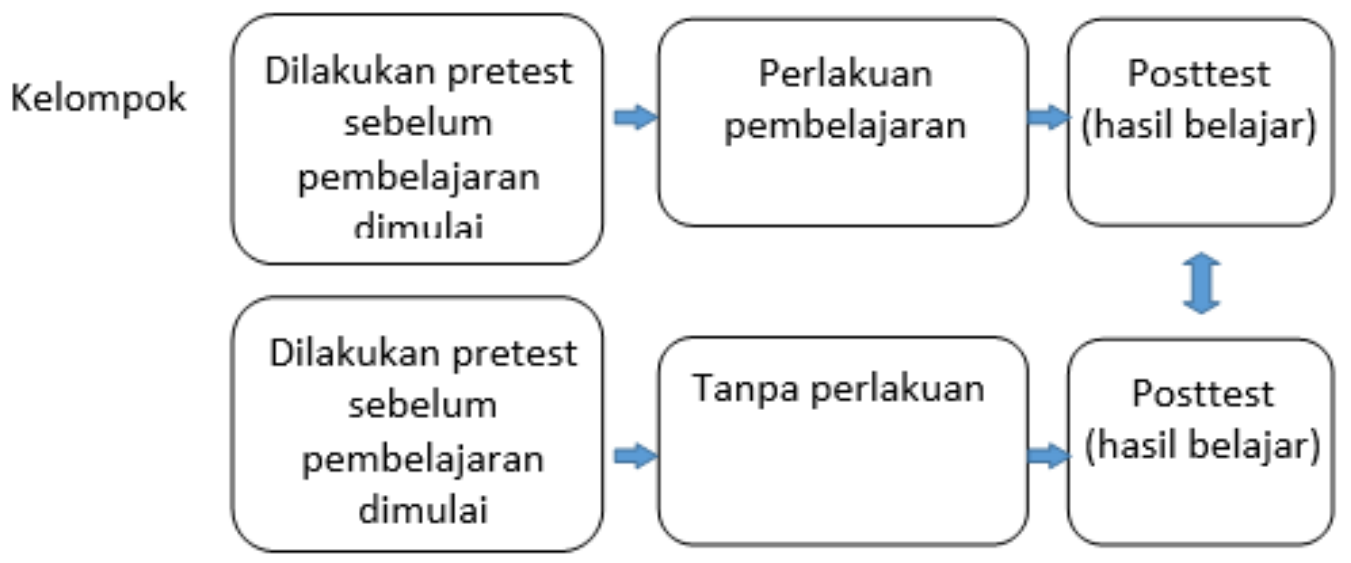

perlakuan:

Kelompok

perlakuan: 
Teknik pengumpulan data yang digunakan adalah teknik tes. Pre-test dilakukan untuk mengambil data kemampuan awal siswa, sedangkan post-test dilakukan untuk menguji pengaruh perlakuan (Knapp, 2016).

Pihak yang terlibat dalam penelitian antara lain: peneliti yang berperan sebagai perancang penelitian sekaligus observer saat penelitian dilakukan, guru mata pelajaran Prakarya yang berperan sebagai pelaksana lapangan, dan siswa kelas $X$ sebagai subyek penelitian.

Analisis data penelitian ini dimulai dengan analisis data uji prasyarat, yaitu:

\section{Uji Normalitas}

Langkah ini bertujuan untuk mengetahui data yang diperoleh terdistribusi normal atau tidak. Apabila data yang dioleh terdistribusi normal, maka untuk selanjutnya langkah yang dilakukan peneliti yaitu uji statistik parametrik, sedangkan apabila data yang diolah tidak terdistribusi normal maka peneliti harus menggunakan uji statistik nonparametrik (Sugiyono, 2016).

Dalam penelitian ini uji normalitas dilakukan menggunakan rumus Chi-kuadrat sebagai berikut:

$$
x^{2}=\sum \frac{\left(f_{o}-f_{h}\right)^{2}}{f_{h}}
$$

Keterangan:

$X^{2} \quad$ : Nilai Chi Kuadrat

$\boldsymbol{f}_{o} \boldsymbol{f}_{o} \quad$ : Frekuensi yang diobservasi

$\boldsymbol{f}_{h} \boldsymbol{f}_{h}$ : Frekuensi yang diharapkan

(Sugiyono, 2016)

\section{Uji Homogenitas}

Uji homogenitas dilakukan untuk menguji/ membandingkan apakah dalam populasi penelitian tersebut tidak jauh berbeda variasinya. Dengan kata lain data yang dianalisis berasal dari populasi yang hampir sama keragamannya. Uji homogenitas atau disebut uji F ini menggunakan rumus sebagai berikut:

$$
F=\frac{\text { Varians Terbesar }}{\text { Varians Terkecil }}
$$

\section{Uji Hipotesis}

Dalam penelitian ini uji homogenitas digunakan untuk menguji hasil belajar siswa yang sudah diberikan perlakuan menggunakan blended learning berbasis flipped classroom apakah lebih baik dari pada siswa yang menggunakan metode blended learning menggunakan media pembelajaran maka digunakan uji-t ( $t$-test). Uji-t digunakan untuk proses analisis data dimana hasilnya merupakan keputusan/kesimpulan yang didasakan pada hipotesis. T-test dalam analisis data statistika menggunakan rumus sebagai berikut:

$$
t=\frac{\overline{\mathrm{x}}_{1}-\overline{\mathrm{x}}_{2}}{\sqrt{\frac{\left(n_{1}-n_{2}\right) S_{1}^{2}+\left(n_{2}-1\right) S_{2}^{2}}{n_{1}+n_{2}-2}\left(\frac{1}{n_{1}}+\frac{1}{n_{2}}\right)}}
$$

Keterangan:

$\begin{array}{ll}\overline{\mathrm{x}}_{1} \overline{\mathrm{x}}_{1} & \text { : rata-rata sampel } 1 \\ \overline{\mathrm{x}}_{2} \overline{\mathrm{x}}_{2} & \text { : rata-rata sampel } 2 \\ S_{1}^{2} S_{1}^{2} & \text { : Varians sampel } 1 \\ S_{2}^{2} S_{2}^{2} & \text { : Varians sampel } 2 \\ n_{1} n_{1} & \text { : Jumlah sampel kelas kontrol } \\ n_{2} n_{2} & \begin{array}{l}\text { : Jumlah sampel kelas } \\ \text { eksperimen }\end{array}\end{array}$

(Sugiyono, 2016)

\section{HASIL DAN PEMBAHASAN Uji Normalitas}

Uji-normalitas dalam penelitian ini dilakukan menggunakan Shapiro-Wilk. Dengan dasar pengambilan keputusan sebagai berikut; (a) jika data $>0,05$ maka data terdistribusi normal dan (b) jika data < 0,05 maka data penelitian tidak terdistribusi normal(Shapiro \& Wilk, 2015). Sedangkan apabila data yang diolah tidak terdistribusi normal maka peneliti harus menggunakan uji statistik non-parametrik.

Tabel 2. Uji Normalitas Data Kelas Eksperimen

\begin{tabular}{llll}
\hline & Signifikansi & Keterangan & Kesimpulan \\
\hline Pre-test & 0,338 & Sig. $>0,005$ & Normal \\
Post-test & 0,397 & Sig. $>0,005$ & Normal \\
\hline
\end{tabular}


Tabel di atas membuktikan bahwa data telah terdistribusi normal dengan nilai signifikansi 0,338 pada saat pretest kelas eksperimen dan 0,397 pada saat post-test. Dimana nilai tersebut $>0,005$ yang berarti sampel kelas eksperimen.

\section{Uji Normalitas Kelas Kontrol}

Tabel 3. Uji Normalitas Data Kelas Kontrol

\begin{tabular}{llll}
\hline & Signifikansi & Keterangan & Kesimpulan \\
\hline Pretest & 0,060 & Sig. $>0,005$ & Normal \\
Posttest & 0,103 & Sig. $>0,005$ & Normal \\
\hline
\end{tabular}

Dari tabel di atas dapat diketahui bahwa data kelompok/kelas kontrol memiliki nilai signifikansi 0,060 pada saat pretest dan 0, 103 pada saat posttest. Dimana nilai tersebut $>0,005$ yang berarti data sampel kelas kontrol tersebut terdistribusi normal.

\section{Uji Homogenitas}

Uji homogenitas dilakukan untuk menguji varian data pada beberapa distribusi (Latuconsina, 2018). Berdasarkan analisa terhadap data nilai hasil belajar kedua kelompok diperoleh data sebagai berikut:

Tabel 4. Data Dasar Uji Homogenitas (Pretest)

\begin{tabular}{lllll}
\hline \multicolumn{1}{c}{ Kelas } & $\begin{array}{l}\text { Levene } \\
\text { Statistic }\end{array}$ & Sig. & Keterangan & Kesimpulan \\
\hline $\begin{array}{l}\text { Eksperimen } \\
\text { Kontrol }\end{array}$ & 1,086 & 0,304 & Sig.>0,05 & Homogen \\
\hline
\end{tabular}

Tabel di atas menunjukkan bahwa nilai probabilitas 0, $304>0,05$. Maka dapat diinterpretasikan kemampuan awal siswa antar kelompok adalah setara atau homogen.
Sedangkan homogenitas hasil belajar setelah mendapatkan perlakuan dapat dilihat pada kolom di bawah ini

Tabel 5. Data Dasar Uji Homogenitas (Posttest)

\begin{tabular}{lllll}
\hline Kelas & $\begin{array}{l}\text { Levene } \\
\text { Statistic }\end{array}$ & Sig. & Keterangan & Kesimpulan \\
\hline $\begin{array}{l}\text { Eksperimen } \\
\text { Kontrol }\end{array}$ & 0,001 & 0,975 & Sig.>0,05 & Homogen \\
\hline
\end{tabular}

Berdasarkan tabel di atas dapat diketahui bahwa nilai probabilitas 0, $975>0,05$. Dengan demikian dapat interpretasikan bahwa kemampuan siswa setelah mendapatkan perlakuan pada kelompok eksperimen dan kelompokkontroladalahsetaraatauhomogen. Sedangkan homogenitas keseluruhan hasil belajar kelompok eksperimen dan kelompok kontrol dapat dilihat pada tabel berikut:

\section{Uji Hipotesis}

Setelah data yang diperoleh menunjukkan bahwa terdistribusi normal dan homogen maka selanjutnya data diolah kembali untuk menguji hipotesis yang telah dirumuskan dalam penelitian ini. Uji hipotesis dilakukan menggunakan teknik uji-t (t-test). Adapun kriteria pengambilan keputusannya adalah sebagai berikut: (a) Apabila nilai probabilitas $>$ 0,05 maka $\mathrm{H}_{0}$ diterima atau "tidak ada pengaruh blended learning berbasis flipped classroom terhadap hasil belajar pada mata pelajaran Prakarya siswa kelas X SMK Ma'arif". (b) Apabila nilai probabilitas $<0,05$ maka $\mathrm{H}_{\mathrm{a}}$ diterima atau "ada pengaruh blended learning berbasis flipped classroom terhadap hasil belajar pada mata pelajaran Prakarya siswa kelas X SMK Ma'arif".

Berdasarkan uji paired sample t-test didapat data sebagai berikut: 
Tabel 6. Paired Samples Test

\begin{tabular}{lllllll}
\hline & & t-test & df. & Sig. (2-tailed) & Kesimpulan \\
\hline Pair1 & $\begin{array}{l}\text { Pre-Test Eksperimen } \\
\text { Eksperimen }\end{array}$ & Post-Test & $-7,623$ & 19 & 0,000 & Berpengaruh \\
\hline Pair2 & $\begin{array}{l}\text { Pre-Test Kontrol - Post-Test Kontrol } \\
\text { Prengaruh }\end{array}$
\end{tabular}

Berdasarkan tabel di atas dapat disimpulkan bahwa ada perbedaan yang signifikan antara hasil kedua test kelas eksperimen 0,000 dan kelas kontrol 0,000 sehingga terdapat perbedaan 0 . bila nilai probabilitas $<0,05$ maka $\mathrm{H}_{\mathrm{a}}$ diterima atau "ada pengaruh Blended

Tabel 7. Hasil Uji t Independent Sample

\begin{tabular}{llllll}
\hline Kelas & $\mathbf{N}$ & Mean & $\mathbf{t}$ & Sig. (2-tailed) & Kesimpulan \\
\hline Eksperimen & 20 & 87.00 & 3.913 & & \\
Kontrol & 20 & 80.45 & 3.913 & 0,000 & Berpengaruh \\
\hline
\end{tabular}

Berdasarkan tabel diatas maka dapat diambil kesimpulan nilai rata-rata antara kelompok eksperimen dan kelompok kontrol tidak identik atau berbeda dengan nilai signifikansinya $0,000<0,05$. Kemudian dapat dideskripsikan bahwa nilai rata-rata dari kelas eksperimen yaitu 87,00 dan kelas kontrol lebih rendah yaitu 80,45. Maka terdapat perbedaan dari nilai rata-rata ke dua kelompok yaitu 6,55.

Berdasarkan uraian di atas dapat disimpulkan bahwa rata-rata hasil belajar siswa yang mendapatkan pembelajaran dengan Blended Learning berbasis flipped classroom lebih tinggi dibandingkan dengan siswa yang mendapatkan pembelajaran dengan Blended Learning menggunakan media pembelajaran.

Dengan demikian dapat diambil keputusan dan dapat terbukti bahwa $\mathrm{H}_{0}$ ditolak dan $\mathrm{H}_{\mathrm{a}}$ diterima karena nilai signifikansinya 0,000 < 0,05 atau $\mathrm{P}<5 \%$ sehingga dapat disimpulkan bahwa "ada pengaruh Blended Learning berbasis flipped classroom pada mata pelajaran Prakarya terhadap hasil belajar siswa kelas X SMK Ma'arif".

\section{Pembahasan}

Penelitian ini adalah penelitian eksperimen yang bertujuan untuk mengetahui pengaruh Blended Learning berbasis flipped classroom
Learning berbasis flipped classroom terhadap hasil belajar pada mata pelajaran Prakarya siswa kelas X SMK Ma'arif".

Berdasarkan uji-t dengan Independent Sample t-test terhadap gain score yang telah dilakukan menghasilkan data sesuai tabel 7. pada matapelajaran Prakarya terhadap hasil belajar dengan subyek penelitian siswa kelas X A dan kelas X B SMK Ma'arif. Subyek yang mendapatkan pembelajaran dengan blended learning berbasis flipped classroom disebut dengan kelas eksperimen, sedangkan kelompok siswa yang tidak menerima perlakuan atau blended learning yang hanya menggunakan media pembelajaran yang disebut kelas kontrol. Cakupan permasalahan penelitian ini terbatas pada pembelajaran menggunakan blended learning berbasis flipped classroom sbagai metode pembelajaran pada mata pelajaran Prakarya tentang simulasi rangkaian listrik. Pengukuran hasil belajarnya juga terbatas pada pengukuran hasil belajar ranah kognitif dan ranah psikomotor menggunakan soal tes dan hasil praktikum. Hipotesis yang diajukan adalah "ada pengaruh blended learning berbasis flipped classroom terhadap hasil belajar pada mata pelajaran Prakarya siswa kelas X SMK Ma'arif".

Setelah melalui beberapa prosedur penelitian, hasil penelitian membuktikan bahwa hipotesis yang diajukan dapat diterima. Berdasarkan uji normalitas terhadap hasil belajar kedua kelompok eksperimen sebelum mendapatkan perlakuan diperoleh nilai signifikansi 0,338 dan 0,060 >0,05 dimana nilai tersebut menunjukkan bahwa 
sampel terdistribusi normal atau memiliki kemampuan yang sama rata.

Penerimaan terhadap hipotesis dapat dibuktikan dengan adanya perbedaan dari semua nilai rata-rata pada kedua kelompok. Pada saat pretest rata-rata nilai kelompok eksperimen 77,00 sedangkan kelompok kontrol 77,05 , dimana selisih nilai rata-rata kedua kelompok tidak terlalu jauh yaitu 0,05 . Melainkan terdapat perbandingan yang signifikan setelah dilakukannya perlakuan terhadap kelas experiment menjadi 87,00dan rata-rata nilai kelompok kontrol adalah 80.45 dari nilai tersebut maka juga diketahui bbahwa nilai perbandingannya sebesar 6,55.

Berdasarkan pengamatan peneliti selama proses pembelajaran Prakarya menggunakan blended learning berbasis Metode flipped classroom memiliki kelebihan yaitu antusiasme siswa dalam merespons materi meningkat karena lebih yang menarik karena mereka mendapat pengalaman belajar baru, keaktifan siswa juga bertambah, siswa lebih fokus terhadap pelajaran, waktu dan tempat belajar yang lebih fleksibel dan materi lebih mudah dimengerti. Terbukti dari sikap siswa kelompok eksperimen lebih tenang, berkonsentrasi, tetapi siswa yang telah diberi perlakuan lebih bisa aktif bertanya dalam pembelajaran.

Menurut Kadry \& Hami (Kurniawati et al., 2019), penerapan model flipped classroom menunjukkan pengalaman yang positif bagi siswa. Senada dengan hal tersebut, diberikannya video yang berisikan materi pembelajaran juga membantu siswa dalam mempelajari materi tersebut secara mandiri di rumah sekaligus dapat menyesuaikan kecepatan belajar mereka masing-masing(Hidayati et al., 2019). Dengan demikian, diperoleh kesimpulan bahwa tanggapan siswa terhadap penerapan blended learning dengan model flipped classroom berbantuan Google Classroom berada pada kategori sangat tinggi.

Dalam menemukan adanya pengaruh tersebut dengan cara compare hasil belajar kedua kelompok dengan perlakuan yang berbeda. Mula-mula dilakukan pre-test kepada masing-masing kelompok untuk menguji kemampuan awal mereka. Selanjutnya diberikan perlakuan atau pembelajaran dengan metode blended learning berbasis flipped classroom kepada kelas eksperimen, sedangkan kelompok kontrol hanya diberikan pembelajaran dengan metode blended learning dengan media pembelajaran. Tahap terakhir yaitu membandingkan kemampuan kedua kelompok eksperimen dan kelompok kontrol setelah mendapatkan perlakuan dan ditemukan hasil "adanya pengaruh blended learning berbasis flipped classroom terhadap hasil belajar pada mata pelajaran Prakarya siswa kelas X SMK Ma'arif".

Hal itu sesuai penelitian terdahulu sebagai berikut: (1) Hal ini juga pernah di teliti dilakukan penelitian yang serupa oleh (Ridha et al., 2016), melalui pengujian hipotesis kelompok eksperimen dengan hasil $(0.000<0.05)$ kemudian hasil dari kelompok kontrol yaitu $(0.003<0.05)$ ia menguji strategi pembelajaran dan menyatakan, bahwa "strategi flipped mastery classroom yang diterapkan pada kelompok eksperimen memberikan pengaruh yang berbeda dengan strategi tradisional yang diterapkan pada kelompok kontrol terhadap perolehan hasil belajar kognitif secara signifikan"(Ridha et al., 2016). (2) Selain itu dalam sebuah artikeljurnal yang ditulis Kunti dan Sunismi menyebutkan "terdapat perbedaan dalam kemampuan presentasi materi pelajaran matematika oleh siswa antara kelas eksperimen (melalui model blended learning dan metode flipped classroom) dan kelas kontrol (melalui model pembelajaran konvensional)" (Kunti Farhatana TS1, Sunismi2, 2019). Dengan hasil analisis data uji hipotesis sebesar $(0,000<0,05)$.

\section{SIMPULAN}

Dari hasil penelitian di atas maka dapat penulis simpulkan "adanya perbedaan blanded learning berbasis flipped classroom". Dengan nilai rata rata 87,00 untuk kelas eksperimen. Dan 80.45, dengan selisih 6,55. Kemudian dengan uji paired independent sample didapatkan nilai $0,000<0,05$ sig. $<5 \%$ maka dapat disimpulkan adanya pengaruh blended learning berbasis flipped classroom terhadap hasil belajar siswa kelas X SMK Ma'arif. 


\section{DAFTAR PUSTAKA}

Abdul Hakim, Punadji Setyosari, I Nyoman Sudana Degeng, D. K. (2016). Pengaruh Strategi Pembelajaran (Pembelajaran Berbasis Proyek Vs Pembelajaran Langsung) Dan Motivasi Belajar Terhadap Pemahaman Konsep Dan Keterampilan Motorik.

Abidin, Z., Praherdhiono, H., Pramono Adi, E., \& Prihatmoko, Y. (2019). Learning Design In Online Learning With Avod. Https:// Doi.Org/10.2991/Icet-18.2018.30

Adhani, A. (2014). Pengaruh Strategi Pembelajaran Reciprocal Teaching Dan Hasil Belajar Kognitif Biologi. Jurnal Pendidikan Sains.

Al Aslamiyah, T., Setyosari, P., \& Praherdhiono, H. (2019). Blended Learning Dan Kemandirian Belajar Mahasiswa Teknologi Pendidikan. Jurnal Kajian Teknologi Pendidikan.

Baihaqi, M. B. (2017). Pendidikan Dan Digitalisasi Di Era Milenial. Sabtu, 23/12/17.

Bergmann, J., \& Sams, A. (2014). Flip Your Classroom Reach Every Student In Every Class Every Day. In Get Abstract Compressed Knowledge. Https://Doi. Org/10.1111/Teth.12165

Capone, R., De Caterina, P., \& Mazza, G. A. G. (2017). Blended Learning, Flipped Classroom And Virtual Environment: Challenges And Opportunities For The 21st Century Students. Edulearn17 Proceedings. Https://Doi. Org/10.21125/Edulearn.2017.0985

Dewi, E. R. (2018). Metode Pembelajaran Modern Dan Konvensional Pada Sekolah Menengah Atas. Pembelajar: Jurnal Ilmu Pendidikan, Keguruan, Dan Pembelajaran. Https://Doi. Org/10.26858/Pembelajar.V2i1.5442

Dwiyogo, W. (2014). Analisi Kebutuhan Pengembangan Model Rancangan Pembelajaran Berbasis Blended Learning (Pbbl) Untuk Meningkatkan Hasil Belajar Pemecahan Masalah. Jurnal Pendidikan Dan Pembelajaran (Jpp).

Dwiyogo, W. (2018). Developing A Blended Learning-Based Method For Problem-
Solving In Capability Learning. Tojet - The Turkish Online Journal Of Educational Technology.

Ekayati, R. (2018). Implementasi Metode Blended Learning Berbasis Aplikasi Edmodo. Jurnal Teknologi Informasi Dan IImu Komputer.

Flammer, C., \& Luo, J. (2017). Corporate Social Responsibility As An Employee Governance Tool: Evidence From A Quasi-Experiment. Strategic Management Journal. Https://Doi. Org/10.1002/Smj.2492

Graham, M. J., \& Borgen, J. (2018). Google Classroom. In Google Tools Meets Middle School. Https://Doi. Org/10.4135/9781506360188.N3

Hidayati, A., Adi, E., \& Praherdhiono, H. (2019). Bangan Media Video Pembelajaran Untuk Meningkatkan Pemahaman Materi Gaya Kelas Iv Di Sdn Sukoiber 1 Jombang. Jinotep (Jurnal Inovasi Dan Teknologi Pembelajaran) Kajian Dan Riset Dalam Teknologi Pembelajaran. Https://Doi.Org/10.17977/ Um031v6i12019p045

Husamah, H. (2015). Blended Project Based Learning: Metacognitive Awareness Of Biology Education New Students. Journal of Education And Learning (Edulearn). Https://Doi.Org/10.11591/ Edulearn.V9i4.2121

Knapp, T. R. (2016). Why Is The One-Group Pretest-Posttest Design Still Used? In Clinical Nursing Research. Https://Doi. Org/10.1177/1054773816666280

Kunti Farhatana Ts1, Sunismi2, S. S. F. (2019). Pemahaman Konsep Dan Kemampuan Komunikasi Matematika Siswa Menggunakan Model Blended Learning Dan Flipped Classroom Materi Perpangkatan Dan Bentuk Akar Kelas Ix Smp Wahid Hasyim Malang (P. 12).

Kurniawati, M., Santanapurba, H., \& Kusumawati, E. (2019). Penerapan Blended Learning Menggunakan Model Flipped Classroom Berbantuan Google Classroom Dalam Pembelajaran Matematika Smp. Edu-Mat: Jurnal Pendidikan Matematika, 7(1), 8-19. Https://Doi.Org/10.20527/Edumat. 
V7i1.6827

Latuconsina, N. D. (2018). Penelitian Eksperimen. In Metode Penelitian Kesehatan. Https://Doi.Org/10.4161/ Cib.26901

Maharani, N., \& Kartini, K. S. (2019). Penggunaan Google Classroom Sebagai Pengembangan Kelas Virtual Dalam Keterampilan Pemecahan Masalah Topik Kinematika Pada Mahasiswa Jurusan Sistem Komputer. Pendipa Journal of Science Education. Https:// Doi.Org/10.33369/Pendipa.3.3.167-173

Mehring, J. (2017). The Flipped Classroom. In Innovations In Flipping The Language Classroom: Theories And Practices. Https://Doi.Org/10.1007/978-981-106968-0_1

Mtebe, J. S. (2015). Learning Management System Success: Increasing Learning Management System Usage In Higher Education In Sub-Saharan Africa. International Journal of Education And Development Using Information And Communication Technology.

Pane, A., \& Darwis Dasopang, M. (2017). Belajar Dan Pembelajaran. Fitrah:Jurnal Kajian IImu-IImu Keislaman, 3(2), 333. Https://Doi.Org/10.24952/Fitrah. V3i2.945

Panje, M., Sihkabuden, S., \& Toenlioe, A. (2016). Pengembangan Video Pembelajaran Bahasa Indonesia Teknik Membaca Puisi. Jurnal Pendidikan Teori, Penelitian, Dan Pengembangan. Https://Doi.Org/10.17977/Jp.V1i8.6617

Praherdhiono, H., Adi, E. P., Prihatmoko, Y., Oktaviani, H. I., \& Nindigraha, N. (2019). Contructing The Learning Democracy Of Life Based Learning In Lms And Mooc. International Journal of Recent Technology And Engineering.
Ridha, M., Setyosari, P., \& Kuswandi, D. (2016). Pengaruh Flipped Mastery Classroom Terhadap Perolehan Hasil Belajar Kognitif Mahasiswa. Jurnal Pendidikan - Teori, Penelitian, Dan Pengembangan, 1(4), 655-661. Https:// Doi.Org/10.17977/Jp.V1i4.6211

Schwab-Cartas, J., \& Mitchell, C. (2015). A Tale Of Two Sites: Cellphones, Participatory Video And Indigeneity In Community-Based Research. Mcgill Journal of Education. Https://Doi. Org/10.7202/1033549ar

Shapiro, \& Wilk, M. B. (2015). The ShapiroWilk And Related Tests For Normality. Statistics.

Spanjers, I. A. E., Könings, K. D., Leppink, J., Verstegen, D. M. L., De Jong, N., Czabanowska, K., \& Van Merriënboer, J. J. G. (2015). The Promised Land Of Blended Learning: Quizzes As A Moderator. In Educational Research Review. Https://Doi.Org/10.1016/J. Edurev.2015.05.001

Sugiyono. (2016). Metodologi Penelitian Kuantitatif, Kualitatif, Dan R\&D. In CV Alfabeta. Https://Doi.Org/Https://Doi. Org/10.3929/Ethz-B-000238666

Wentzel, J., Van Der Vaart, R., Bohlmeijer, E. T., \& Van Gemert-Pijnen, J. E. W. C. (2016). Mixing Online And Face-To-Face Therapy: How To Benefit From Blended Care In Mental Health Care. Jmir Mental Health. Https://Doi.Org/10.2196/ Mental.4534

Wulandari, V., Abidin, Z., \& Praherdhiono, H. (2019). Pengembangan Media Pembelajaran E-Book Infografis Sebagai Penguatan Kognitif Siswa X Mia. Jurnal Kajian Teknologi Pendidikan.

Yuhefizar. (2016). 10 Pengertian Website Menurut Para Ahli | Situs Berita Pendidikan. 28 February 2016. 